\title{
The introduction of corporate governance codes in a transitional economy and its impact on compliance with mandatory disclosures: The case of Egypt
}

\author{
Marwa Hassaan ${ }^{\mathrm{a}}$, \\ ${ }^{a}$ Mansoura Business School, Mansoura, Egypt
}

\begin{abstract}
This study aims to investigate the influence of the introduction of a corporate governance code in 2005 on the levels of compliance with mandatory IFRSs disclosure requirements by companies listed on the Egyptian Exchange (EGX) as a leading stock exchange in the Middle East. Using a disclosure index derived from mandatory IFRSs disclosure requirements for the fiscal year 2007, this study measures the levels of compliance by a sample of 75 non-financial companies listed on the focus stock exchange. This study extends the financial reporting literature and the emerging markets disclosure literature by being the first to investigate the influence of corporate governance requirements for best practices on the levels of compliance with mandatory IFRSs disclosure requirements by companies listed on the EGX. Results provide evidence of the lack of influence of corporate governance best practices on the levels of compliance with mandatory IFRSs disclosure requirements as it is not yet part of the cultural values within the Egyptian context. These findings are consistent with the notions of the proposed theoretical foundation.
\end{abstract}

Keywords: IFRSs; Egypt; EGX; ECCG; Board Leadership; Board independence; Board size; Ownership Structure; Isomorphism; Gray’s Accounting Subcultural Model; Financial Economics Theories.

\section{(C) 2013 Published by SSBFNET}

\section{Introduction}

Across the globe a series of events over the last two decades placed corporate governance at the top of the agenda for business communities, international financial institutions, governments, and capital market regulators. Specifically, these were the Asian financial crisis and the high-profile corporate scandals such as WorldCom, Enron, Lehman Brothers and Tyco. Furthermore, in academia, the topic continues to attract much attention from researchers (e.g., Beasley, 1996; Haniffa \& Cooke, 2002; Ghazali \& Weetman, 2006; Brown 2007; Ezat \& El-Masri, 2008; Felo, 2009; Al-Akra et al., 2010a,b; Samaha, 2010; Samaha \& Dahawy, 2010; 2011). Corporate governance is concerned with the system of directing and controlling companies, and it is the responsibility of BOD (Cadbury Committee Report, 1992). It is a fundamental element in improving economic efficiency and growth as well as enhancing investor confidence (OECD, 2004). "Corporate governance involves a set of relationships between a company's management, its board, its shareholders and other stakeholders. Corporate governance also provides the structure through which the objectives of the company are set, and the means of attaining those objectives and monitoring performance are determined" (OECD, 2004: 11). The BOD actions are subject to laws, regulations and shareholders in general meeting and the role of shareholders in governance is to appoint the directors and auditors and to make sure that the governance structure is appropriate (Cadbury Committee Report, 1992).

The development of corporate governance is a global phenomenon, influenced by legal, cultural, ownership, and other structural differences (Mallin, 2009), but as yet there is no widely accepted paradigm or theoretical foundation in its respect (Tricker, 2009). For transitional economies, good corporate governance practice may be essential to guarantee the success of their reform programmes and to create a healthy investment climate. However, the corporate governance codes for best practice were initiated in developed countries and only recently introduced in developing ones. Hence, its contribution towards enhancing capital market performance in such countries is subject to the extent to which the

\footnotetext{
${ }^{\text {a }}$ Corresponding author, hassanm3@aston.ac.uk.
} 
conditions for robust governance practice are consistent with the existing values, past experiences and the needs of all parties involved in the financial reporting process. It is expected, therefore, to be some time before the impact of applying corporate governance can be measured in developing contexts as this needs to develop, and favourable attitudes and belief must be formed as well as efforts being made to develop the human resource capabilities to apply corporate governance requirements for best practice.

The careful review of the Egyptian modern history demonstrates that the Arab Republic of Egypt has always been the regional leading reformer. The harmonisation of the Egyptian Accounting Standards with IASs/IFRSs began with the launch of the government's economic reform and structural adjustment programme in the early 1990s which commenced under pressure from the international institutions specifically the WB and the IMF as a condition of their providing financial support to Egypt (Dahawy \& Conover, 2007; Dahawy \& Samaha, 2010). Mandating IFRSs enabled Egypt to access international exchanges, saved time and effort needed for developing national standards from scratch, improved fairness of financial statements prepared by Egyptian companies (Samaha \& Dahawy, 2011: 63). The Cairo and Alexandria Stock Exchanges currently referred to as the Egyptian Exchange (EGX) are among the oldest stock exchanges worldwide, the latter being developed in 1888 and the former in 1903. For almost 40 years they experienced stagnation during the nationalisation regime until they were revitalised in 1992 as one entity with two trading floors (CIPE, 2003; Desoky, 2009).

The new listing rules issued by the Capital Market Authority (CMA) in 2002 aimed to enhance the implementation of corporate governance best practice by listed companies, and include comprehensive disclosure requirements (Articles 12 to 19), and detailed requirements for financial statements preparation and presentation (Articles 20 to 33). Article 4 requires the presentation of complete information about the company's board members. Additionally, Articles 34 and 35 indicate delisting rules which compel publicly-listed companies to make a commitment to disclosure requirements, or to risk delisting. The application of the aforementioned listing rules resulted in delisting of 99 non-compliant companies in 2003 (ROSC, 2004).

The assessment of corporate governance practices in the Egyptian Capital Market by the WB in 2004 revealed that Egypt applied $82 \%$ of the OECD principles (ROSC, 2004), indicating improvements over time. The major areas of improvement include: basic shareholders' rights, cost/benefit of voting, and disclosure standards (ROSC, 2004). The first Egyptian Code of Corporate Governance (ECCG) was introduced in 2005. This code is based on the OECD corporate governance principles. The code indicates that its rules should be considered as an addition to the corporaterelated provisions stated under various laws as well as the executive regulations and decrees regarding their implementation. The ECCG rules are neither mandatory nor legally binding; rather, they promote and regulate responsible and transparent behaviour in managing corporations according to international best practice and aim to ensure equilibrium between various party interests (Dahawy, 2007; GAFI, 2007; UNCTAD, 2007; Samaha \& Dahawy, 2011).

A number of studies have been conducted in the last decade for the purpose of investigating the relationship between corporate governance and corporate disclosure practices in different countries (e.g., Chen \& Jaggi, 2000; Haniffa \& Cooke, 2002; Gul \& Leung, 2004; Abdelsalam \& Street, 2007; Ezat \& El-Masry, 2008; Felo, 2009; Al-Akra et al., 2010a,b; Samaha, 2010; Samaha \& Dahawy, 2010; 2011; Abed et al., 2011; Alanezi \& Albuloushi, 2011). However, to the best of the researcher's knowledge this study is the first to examine the influence of corporate governance structures (namely, board independence, board leadership, board size and ownership structure) on the overall compliance with mandatory IFRSs disclosure requirements in the Egyptian context. As disclosure lies at the core of all corporate governance statutes and codes, investigating the association between corporate governance structures and the levels of compliance with IFRSs disclosure requirements is expected to enrich financial disclosure as well as corporate governance literature.

This paper addresses three research questions: (i) what is the extent of compliance with mandatory IFRSs disclosure requirements by companies listed on the EGX?; (ii) how could differences in the levels of compliance with the IFRSs be explained by corporate governance structures?; (iii) to what extent do institutional isomorphism theory, cultural theories and economic-based theories help to explain the influence of corporate governance structures on the levels of compliance with IFRSs disclosure requirements within the Egyptian context? 
In order to answer the above mentioned research questions, the remaining part of the paper is organised as follows: A literature review is provided in Section 2. Section 3 develops and formulates research hypotheses. Section 4 describes sample selection, data collection, and research methods. Results and analysis are presented in Section 5. Finally, Section 6 concludes.

\section{Literature Review and Formulation of Research Hypothesis}

Financial disclosure is a rich field of empirical enquiry (Healy \& Palepu, 2001). More recently, researchers became more concerned with investigating the issue of adopting a unified set of accounting standards worldwide. This line of research is concerned with investigating the applicability of full compliance with the IFRSs and the association between levels of compliance with the IFRSs and disclosure environment attributes. The importance of evaluating the levels of compliance with mandatory disclosure requirements is proved by the findings of this line of research which reports the absence of de facto compliance with mandatory disclosure requirements in emerging markets (e.g., Abdelsalam \& Weetman, 2003; Glaum \& Street, 2003; Owusu-Ansah \& Yeoh, 2005; Samaha, 2006; Dahawy \& Conover, 2007; Al-Shammari et al., 2008; Al-Akra et al., 2010a).

For emerging capital markets good corporate governance practices may be essential for a sound success of their reform programmes and for reserving a healthy investment environment. Following a series of events that took place over the last two decades addressed by the Asian financial crisis and the wide spread of high-profile corporate scandals such as WorldCom and Enron, empirical research into accounting disclosure practices particularly in emerging capital markets began to consider the impact of corporate governance structures on disclosure practices in transitional economies. The development of corporate governance is a global occurrence thus is influenced by legal, cultural, ownership and other structural differences (Mallin, 2009: 13). To date corporate governance does not have a widely accepted paradigm or theoretical foundation (Tricker, 2009: 233). Transparency, fairness and accountability are the core values of corporate governance. Stemming from the desire to enhance access to more capital that is necessary to achieve economic development and globalise their economies, corporate governance practices have been brought in the spotlight in developing countries. In this regard many researchers highlight the influence of corporate board characteristics and ownership structure (e.g., Eng \& Mak, 2003, Ghazali \& Weetman, 2006; Ezat \& El-Masry, 2008; Al-Akra et al., 2010a,b) on disclosure practices of companies listed on emerging stock exchanges. However, I suggest that as corporate governance was initiated in developed countries and as it is newly introduced in developing countries, its contribution to enhancing capital markets' performance is subject to the extent to which the requirements for good corporate governance practices are consistent with the existing values, past experiences and the needs of all parties involved in the financial reporting process. Otherwise, it is expected to take some time until the impact of corporate governance can be measured. This is because it needs developing an understanding, forming a favourable attitude and belief and developing the skills required to apply corporate governance best practice.

\section{Development of Hypotheses}

This section illustrates the development of the research hypotheses formulated to examine the influence of board of directors (BOD) characteristics (BOD independence, BOD leadership and BOD size) and ownership structure (government ownership ratio, management ownership ratio, private ownership ratio and public ownership ratio) on the levels of compliance with IFRSs disclosure requirements in the Egyptian context. Additionally, the section illuminates those variables to be used as control variables (company size, profitability, gearing, liquidity, type of business activity, and type of audit firm) as identified in previous research as being associated with financial disclosure practices and compliance. In each case expectation is stated based on prior literature.

\subsection{Board Independence}

Board independence is an outcome of the number of independent directors in the board of directors (BOD). Board independence is an important governance mechanism that is supported by corporate governance reforms in Egypt (Samaha and Dahawy, 2010, 2011). The lack of empirical evidence with respect to the association between board independence and levels of compliance with mandatory IFRSs disclosure requirements within the Egyptian context supports the need for further investigation. 
Findings of prior research that examined the association between board independence and financial disclosure are mixed which makes it difficult to predict the relationship between board independence and levels of compliance with the IFRSs in the scrutinised context. Some researchers report a positive relationship (e.g., Arcay \& Vazquez, 2005; Cheng \& Courtenay, 2006; Abdelsalam \& Street, 2007; Abdelsalam \& Elmasry, 2008; Ezat \& Elmasry, 2008; Felo, 2009). In contrast, some researchers report a negative relationship (Eng \& Mak, 2003; Gul \& Leung, 2004; Muslu, 2005) while other researchers did not find any relationship (Haniffa \& Cooke, 2002; Ghazali \& Weetman, 2006). Accordingly, the first research hypothesis can be stated as follows:

H1: There is no relationship between BOD independence and the extent of compliance with the IFRSs disclosure requirements.

\subsection{Board Leadership}

Board leadership is a governance issue that concerns with whether the chief executive officer (CEO) is also the Chair of the board of directors. Separating the two positions has the potential to improve the monitoring function of the board and to reduce the advantages gained by withholding information, hence to improve the quality of reporting (Arcay \& Vazquez, 2005). Combining both roles reduces the availability of independent evaluation of the CEO's performance as the CEOs themselves will select which information to be provided to other directors (Jensen, 1993). In addition, role duality creates a strong individual power base that could impair board independence thus the effectiveness of its governing function may be compromised (Abdelsalam \& Elmasry, 2008). The results of prior research investigated the association between board leadership and levels of financial disclosure are mixed. Some studies show that role duality is significantly associated with a lower level of financial disclosure (e.g., Haniffa \& Cooke, 2002; Gul \& Leung, 2004; Arcay \& Vazquez, 2005; Abdelsalam \& Elamasry, 2008) while Ghazali \& Weetman (2006) report an insignificant relationship. On the other hand, some empirical research show that there is no association between role duality and financial disclosure or reporting quality (Cheng \& Courtenay, 2006; Ghazali \& Weetman, 2006) and one study (Felo, 2009) reports a positive relationship between role duality and financial disclosure practices. The contradictory nature of these results raises the need to re-examine this relationship and make it difficult to predict the type of the relationship between board leadership and levels of compliance with the IFRSs in the scrutinised MENA capital markets. Accordingly, the second research hypothesis can be stated as follows:

H2: There are no statistically significant differences in the levels of compliance with the IFRSs disclosure requirements between companies that separate the positions of the CEO and the Chair and those that do not.

\subsection{Board Size}

Board size is one of the corporate governance mechanisms that help in aligning management and shareholder interests (Arcay \& Vazquez, 2005; Abdelsalam \& Street, 2007). Good governance practices recommend limitations to the size of the BOD (Arcay \& Vazquez, 2005), but there is no general consensus on the optimum. Findings from previous research into the association between board size and levels of financial disclosure are mixed. Some researchers report a positive relationship (Barako et al., 2006; Ezat \& El-Masry, 2008; Al-Akra et al., 2010a). However, others find no association (Arcay \& Vazquez, 2005; Abed et al., 2011). The contradictory nature of these results and the nonavailability of a study that investigates the association between board size and levels of compliance with IFRSs disclosure requirements in the Egyptian context make it difficult to predict the type of the relationship between board size and levels of compliance with IFRSs. Accordingly, the third research hypothesis can be stated as follows:

H3: There is no significant statistical relationship between BOD size and the extent of compliance with the IFRSs disclosure requirements.

\subsection{Ownership Structure}

Ownership structure is defined by Denis \& McConnell (2003: 3) as "The identities of a firm's equity holders and the sizes of their positions". The ownership structure of a firm may be a possible determinant of its disclosure practices (Eng \& Mak, 2003; Arcay \& Vazquez, 2005). High levels of concentration of capital may be accompanied by the owner's considerable involvement in the firm's management, which in turn may lead to unrestricted access to information, thus may limit the demand hence the supply for company information and vice versa (Haniffa \& Cooke, 2002; Arcay \& Vazquez, 2005; Ezat \& El-Masry, 2008). On the other hand, when share ownership is widely held, the potential for conflicts of interests between the principal and the agent is greater than in closely held companies. As a 
result, disclosure is likely to be greater in widely held companies to enable the principal to effectively monitor whether his/her economic interests are optimised and whether the agent acts in the best interests of the principal as an owner of the firm ( Chen \& Gray, 2002). Based on the review of the patterns of ownership structure in the scrutinised companies and the availability of ownership structure related data for these companies, this study examines the influence of ownership structure on the levels of compliance with the IFRSs in the Egyptian context using four distinct measures; government ownership (defined as the percentage of company shares owned by the government), management ownership (defined as the percentage of company shares owned by company management), private ownership (defined as the percentage of company shares owned by private shareholders) and public ownership (defined as the percentage of company shares owned by the free float that is less than 5\%).

\subsubsection{Government ownership}

The results of prior studies that examined the association between government ownership and levels of financial disclosure are mixed. For instance, Eng \& Mak, (2003) report a positive relationship while Naser et al. (2006) report a negative relationship and Ghazali \& Weetman (2006) find a negative but insignificant relationship. Accordingly, built on the above discussion research hypothesis (4a) can be stated as follows:

H4a: There is no significant statistical relationship between government ownership ratio and the extent of compliance with the IFRSs disclosure requirements.

\subsubsection{Management Ownership}

The results of the majority of prior studies that examined the association between management ownership and levels of financial disclosure show a negative association (e.g., Eng \& Mak, 2003; Arcay \& Vazquez, 2005; Ghazali \& Weetman, 2006; Abdelsalam \& El-Masry, 2008). Thus, the effect of management ownership on levels of compliance with the IFRSs is expected to be substitutive. Accordingly, research hypothesis (4b) can be stated as follows:

H4b: There is a significant negative statistical relationship between management ownership ratio and the levels of compliance with the IFRSs disclosure requirements.

\subsubsection{Private Ownership}

Similar to government ownership, there is no consensus among prior researchers regarding the influence of private ownership on the levels of compliance with financial disclosure requirements. Some researchers report that private ownership may be a complementary (Haniffa \& Cooke, 2002). On the contrary, some researchers report that concentrated ownership and financial disclosure are substitutes (dominance of private shareholders reduces levels of financial disclosure) such as Naser et al. (2006) while others report no association between the dominance of private ownership and levels of financial disclosure (Suwaidan, 1997; Depoers, 2000). Accordingly, research hypothesis (4c) can be stated as follows:

H4c: There is no statistically significant relationship between private ownership ratio and the extent of compliance with IFRSs disclosure requirements.

\subsubsection{Public Ownership}

The results of most prior studies show a positive association between public ownership and levels of financial disclosure (e.g., Haniffa \& Cooke, 2002; Al-Htaybat, 2005; Arcay \& Vazquez, 2005). However, Al-Akra et al. (2010b) results support the existence of a significant negative association and Naser et al. (2002) and Al-Akra et al. (2010a) findings do not support the existence of any association between public ownership ratio and the levels of compliance with IFRSs. Accordingly, research hypothesis $4 \mathrm{~d}$ can be stated as follows:

H4d: There is no significant statistical relationship between the public ownership ratio and the extent of compliance with IFRSS disclosure requirements.

\subsection{Control Variables}

Based on the findings of prior researchers (Eng \& Mak, 2003; Akhtaruddin, 2005; Aksu \& Kosdag, 2006 and Naser et al., 2006) firm size is included as a control variable and a positive association between firm size and levels of 
compliance with the IFRSs disclosure requirements is anticipated. Evidence relating to the association between firm profitability and levels of financial disclosure is mixed. Some studies report a positive association between these variables (Akhtaruddin, 2005; Aksu and Kosedag, 2006), while others report a significant negative association between them (Belkaoui and Kahl, 1978; Wallace and Naser, 1995). Consequently, the direction of the relationship between profitability and compliance with the IFRSs is unpredictable.

Evidence from prior research on the association between firm liquidity and levels of financial disclosure is mixed. Belkaoui and Kahl (1978) report a positive relationship. In contrast, Naser et al. (2002) find a negative relationship. Consequently, liquidity is used in this study as a control variable, recognising that the direction of the relationship between company liquidity and compliance levels is unpredictable.

Evidence regarding the association between gearing and level of financial disclosure is mixed. Some studies report a positive relationship (Naser, 1998; Naser et al., 2002; Barako et al., 2006), whilst others find a negative relationship (Zarzeski, 1996; Eng \& Mak, 2003). Consequently, gearing is employed in this study as a control variable, recognising that the direction of the relationship between the two variables is unpredictable. Based on the evidence provided by prior research that the type of business activity influences its disclosure practices (Haniffa \& Cooke, 2002), type of business activity will be employed in this study as a control variable.

Based on the evidence provided by prior research that there is a relationship between the type of auditor and levels of company disclosure (Glaum \& Street 2003), type of auditor will be employed in this study as a control variable and it is expected that auditing by a big 4 audit firm has a positive impact on the levels of compliance with the IFRSs.

\section{Methodology}

\subsection{Sample Selection}

The annual reports of 2007 for the entire population of non-financial companies listed on the EGX (145 companies) formed the study population. Financial institutions such as banks and insurance companies were excluded because their reports are not comparable with those of non-financial companies as they are subject to other disclosure requirements. Then the following two criteria were applied: The company should have a complete annual report for the year ended 31 December, 2007. There should be information related to corporate governance structure within the company for the year 2007. To meet the first criterion 17 companies were excluded and then 53 companies were excluded to meet the second criterion. Hence, the final sample contained 75 companies.

\subsection{Disclosure Checklist}

To meet the purpose of this study the researcher uses a self-constructed disclosure checklist based on the IFRSs required to be followed by the IASB in preparing the financial statements for the fiscal year beginning January 2007 and which are mandated in the Egyptian context. The disclosure index employed in this study includes 275 IFRSs based items $\mathrm{s}^{\mathrm{b}}$. The disclosure index for each company was calculated as the ratio of the total actual score awarded to the maximum possible score of relevant items applicable for that company. The calculation of the disclosure index (dependent variable) for each company under this approach is as follows:

$$
D I=A D S / M D
$$

Where:

DI refers to the disclosure index $(0 \leqslant \mathrm{DI} \leqslant 1)$.

ADS refers to the aggregate disclosure score for a particular company.

MD refers to the maximum score possible for that company.

\subsection{Data Collection and Regression Model}

The data on the chosen independent variables (see below) were obtained from Egypt for Information Dissemination Company (EGID). The following multiple regression model is proposed:

\footnotetext{
${ }^{\mathrm{b}}$ The disclosure index employed in this study is not presented here to save space but available from author upon request.
} 
$Y j=\beta 0+\beta 1$ board independencej $+\beta 2$ board leadershipj $+\beta 3$ board size $+\beta 4$ government ownership ratioj + $\beta 5$ management ownership ratioj $+\beta 6$ private ownership ratioj $+\beta 7$ public ownership ratioj $+\beta 8$ total assetsj $+\beta 9$ return on assetsj $+\beta 10$ debt to equity $+\beta 1$ lquick ratio $+\beta 12$ type of business activityj $+\beta 13$ type of audit firmj $+\varepsilon j$

Where:

$Y j=$ Disclosure index for companies $(j=1, \ldots, 75)$ which denotes the dependent variable.

$\beta 0=$ The intercept.

$\varepsilon j=$ Error term.

The independent variables consist of seven test variables (board independence, board leadership, board size, government ownership ratio, management ownership ratio, private ownership ratio and public ownership ratio) and six control variables (firm size [proxied by total assets], profitability [proxied by return on assets], gearing [proxied by debt to equity], liquidity [proxied by quick ratio], type of business activity, and type of audit firm). Due to the nonnormality of distribution of dependent and independent variables, it was decided to use non-parametric tests and to run the regression analysis using normal scores as transforming data is a recommended approach in order to modify their distribution to look more normal (Field, 2005) ${ }^{\mathrm{c}}$.

\section{Results and Analysis}

\subsection{Descriptive Statistics}

5.1.1. Descriptive Statistics for the Extent of Compliance with Mandatory IFRSs

The results of the analysis of the 75 annual reports of companies listed on the EGX are demonstrated in table 1.

Table 1: Descriptive Statistics of the Extent of Compliance with Mandatory IFRSs by Companies Listed on the EGX.

\begin{tabular}{lllllll}
\hline Country & Min. \% & Max. \% & Mean \% & $\begin{array}{l}\text { Std. } \\
\text { Deviation }\end{array}$ & $\begin{array}{l}\text { Percentage of } \\
\text { companies above 50\% }\end{array}$ & $\begin{array}{l}\text { Number of companies } \\
\text { above 50\% }\end{array}$ \\
\hline Egypt & 68 & 91 & 80 & 0.04 & 75 & 100
\end{tabular}

Table 1 shows that the average level of compliance with the IFRSs disclosure requirements by non-financial companies listed on the EGX is $80 \%$. The minimum level of compliance was $68 \%$ and the maximum level was $91 \%$ implying that none of the companies listed on the EGX achieved full compliance with mandatory IFRSs disclosure requirements. Hence, de facto compliance with mandatory IFRSs disclosure requirements in the Egyptian context is problematic although the requirements under the ECCG and Capital Market Law mandate full compliance with IFRSs requirements. In most of the cases low compliance levels may be attributed to the preference for secrecy, fear of competition, low non-compliance costs, and weak monitoring. Lack of awareness of the importance of compliance and improved transparency among management of the majority of listed companies are also potential reasons for lack of full compliance with some requirements. Compared to the findings of a more recent study that was conducted on the best performing 15 companies listed on the EGX for the fiscal year 2004 (Dahawy, 2007), a significant increase is seen in the levels of compliance with IFRSs disclosure requirements. The average level of compliance reported by Dahawy and Conover (2007) was $62 \%$ (compared to $80 \%$ in this study) with the minimum compliance level $52 \%$ (compared to $68 \%$ in this study) and the maximum $76 \%$ (compared to $91 \%$ in this study). This difference may be attributed to the use of a more comprehensive disclosure index, and a much larger sample in this study and/or the relative improvement in the monitoring and enforcement functions of the CMA in 2007 (the year of this study) compared to 2004 (the year of Dahawy and Conover's study). However, this disparity supports the proposition that overall progress in compliance levels in the Egyptian context may be a positive sign that the national norms are moving towards compliance but that more time is needed for certain disclosure requirements to become part of the culture of Egyptian corporate management. Thus, progress in compliance levels can be observed over time. That said,

\footnotetext{
${ }^{\mathrm{c}}$ The result of tests of normality is not presented here to save space but available from author upon request.
} 
stringent enforcement and strict punishment would foster full compliance much swifter and overcome the existing barriers to full compliance with IFRSs.

\subsubsection{Descriptive Statistics for Independent Variables}

Table 2 shows that the ratio of independent non-executive directors on the BOD of Egyptian companies ranges from $0 \%$ to $100 \%$, meaning that the BOD of some companies listed on the EGX may consist entirely of executive directors or vice versa. However, on average more than $50 \%$ of the BOD members are independent which agrees with the recommendation of the OECD principles and that of the ECCG.

Table 2: Summary of Descriptive Statistics for Independent Variables.

\begin{tabular}{lllll}
\hline \multirow{2}{*}{ Independent Variable } & \multicolumn{3}{c}{ Egypt (N=75) } \\
\cline { 2 - 5 } & Min. & Max. & Mean & Std. Deviation \\
\hline Board Independence Ratio & 0.00 & 1.00 & 0.5052 & 0.1928 \\
Board Leadership & 0.00 & 1.00 & 0.51 & 0.503 \\
Board Size & 3.00 & 9.00 & 5.17 & 1.855 \\
Government Ownership & 0.00 & 0.98 & 0.1919 & 0.2964 \\
Ratio & & & & \\
Management Ownership & 0.00 & 1.00 & 0.1121 & 0.2361 \\
Ratio & 0.00 & 1.00 & 0.2353 & 0.3231 \\
Private Ownership Ratio & 0.00 & 0.86 & 0.1504 & 0.2429 \\
Public Ownership Ratio & 624.0000 & 11388000 & 522139.500 & 1533462.4 \\
Company Sizea & -0.30 & 0.31 & 0.1343 & 0.0838 \\
Profitability & 0.01 & 2.22 & 0.6798 & 0.3995 \\
Gearing & 0.33 & 8.58 & 2.5580 & 1.5314 \\
Liquidity & 0.00 & 1.00 & 0.35 & 0.479 \\
Type of Business & 0.00 & 1.00 & 0.31 & 0.464 \\
Type of Auditor & & & & \\
\hline
\end{tabular}

In respect of board leadership, the CEO and the Chair positions are held by two different persons in $51 \%$ of the companies listed on the EGX. For board size, it ranges from 3 to 9 members, with an average board size of 5 members. With respect to government ownership ratio, this ranges from $0 \%$ to $98 \%$ with an average of $19 \%$. In terms of the management ownership ratio, this ranges from $0 \%$ to $100 \%$ with an average $11 \%$. The private ownership ratio is seen to range from $0 \%$ to $100 \%$ with an average of $24 \%$. Finally, with respect to public ownership, the ratio ranges from $0 \%$ to $86 \%$ with an average of $15 \%$. The descriptive statistics of the control variables as in Table 2 , show that the average firm size measured in terms of total assets is USD 522139.5 million. Profitability measured in terms of return on assets, indicates that the average profitability in companies listed on the EGX is $13 \%$. The gearing measured in terms of debt to equity, averages 0.68 . The average liquidity is very high (2.56). This implies the high ability of companies listed on the EGX to meet their short term obligations, which reflects the large margin of safety in companies listed on the EGX and their ability to continue as going concerns. This in turn has the potential to attract more direct foreign investments. Finally, the descriptive statistics of the categorical control variables as indicated in Table 2 show that $35 \%$ of the sample companies that are listed on the EGX are non-manufacturing. Also, it is recognised that $31 \%$ of the companies listed on the EGX are audited by non big 4 auditors. This implies that the majority of companies listed on the EGX (69\%) are audited by big 4 affiliates.

5.2. Univariate Analysis

5.2.1. Univariate Analysis - Total Disclosure Index and the Continuous Independent Variables

Table 3 presents the correlation between the overall level of compliance with IFRSs disclosure requirements (total disclosure index) and continuous independent variables within the Egyptian context. Given that the results of the test 
of normality for the total disclosure index show that $\mathrm{P}=.2(\mathrm{P}>.05)$, it was decided to double-check the results of the Spearman Rank Correlation (non-parametric test) using the Pearson Product-moment Correlation (parametric test).

Table 3. Correlation between Total Disclosure Index and Continuous Independent Variables.

\begin{tabular}{lllll}
\hline \multirow{2}{*}{ Independent Variable } & \multicolumn{4}{c}{ Total Disclosure Index } \\
\cline { 2 - 5 } & \multicolumn{2}{c}{ Spearman Rank Correlation } & \multicolumn{2}{c}{ Pearson Product-moment Correlation } \\
\cline { 2 - 5 } & $\begin{array}{l}\text { Correlation } \\
\text { Coefficient (r) }\end{array}$ & $\begin{array}{l}\text { Significance } \\
\text { (two-tailed) }\end{array}$ & $\begin{array}{l}\text { Correlation } \\
\text { Coefficient (r) }\end{array}$ & $\begin{array}{l}\text { Significance } \\
\text { (two-tailed) }\end{array}$ \\
\hline BOD Independence & .072 & .538 & .008 & .945 \\
BOD Size & .052 & .657 & .066 & .574 \\
Government Ownership & .127 & .277 & .139 & .235 \\
Management Ownership & .031 & .790 & .019 & .872 \\
Private Ownership & -.013 & .910 & -.019 & .871 \\
Public Ownership & -.080 & .493 & -.152 & .193 \\
Company Size & .171 & .143 & .051 & .666 \\
Profitability & -.022 & .850 & -.087 & .456 \\
Gearing & -.122 & .297 & -.055 & .642 \\
Liquidity & -.003 & .978 & .042 & .722 \\
\hline
\end{tabular}

As seen in Table 3, the results of both the Spearman Rank Correlation and the Pearson Product-moment Correlation support the non-existence of any significant correlation between the overall level of compliance with mandatory IFRSs disclosure requirements and continuous corporate governance test variables $(\mathrm{P}>.05)$.

These findings support the second research hypothesis (H2: there is no significant statistical relationship between board independence and the extent of compliance with IFRSs disclosure requirements). This agrees with the findings of Haniffa (1999), Haniffa and Cooke (2002), Ghazali and Weetman (2006) and Al-Akra et al. (2010a,b). Compared with the findings of prior studies that investigated the association between corporate governance attributes and disclosure practices within the Egyptian context, these findings do not support those of Samaha and Dahawy (2010; 2011) which report a significant positive relationship between voluntary disclosure levels and board independence. With respect to the association between board size and compliance with mandatory IFRSs disclosure requirements, these findings support the fourth research hypothesis (H4: there is no significant statistical relationship between board size and the extent of compliance with IFRSs disclosure requirements). This agrees with the findings of Lakhal (2003), Arcay and Vazquez (2005) and Cheng and Courtenay (2006). Compared with the findings of prior studies that investigated the association between board size and disclosure practices within the Egyptian context, these findings do not support those of Ezat and El-Masry (2008) which report a significant positive relationship between voluntary internet disclosure and board size.

The lack of correlation between levels of compliance with mandatory IFRSs disclosure requirements and either of board independence or board size within the Egyptian context, supports the proposition that the majority of board members in companies listed on the EGX do not carry out their responsibilities with respect to monitoring management behaviour properly, even when outside directors are recognised on the boards in the Egyptian listed companies, they lack material independence as generally, they are appointed to the board because of their close relationship with executive board members, the Chair or controlling shareholders. They may also lack experience or may have insufficient financial incentive to actively monitor management and protect the interests of minority shareholders. This lends weight to the notions of the institutional isomorphism theory (board members in the Egyptian listed companies, do not contribute to improving the BOD's monitoring function even when they meet the independence criterion, being appointed simply to signal that such companies follow corporate governance best practices, and hence, gain respect, consequently the problem of decoupling will continue as companies will state that financial statements are prepared according to IFRSs while full compliance is absent). Furthermore, the predictions of agency theory and cost-benefit analysis (weak monitoring reduces monitoring costs and weak enforcement of IFRSs reduces non-compliance costs) and Gray's (1988) accounting sub-cultural model (acceptance of secrecy, absence of 
awareness regarding the importance of transparency and the lack of material independence by board members may support management's selective disclosure to avoid competition and protect company reputation, even though the lack of disclosure is in breach of the mandatory requirements).

With respect to the association between government ownership ratio and the levels of compliance with IFRSs disclosure requirements, the findings reported in Table 3 support hypothesis H5a (there is no significant statistical relationship between the government ownership ratio and the extent of compliance with IFRSs disclosure requirements). This result supports the findings of Naser et al. (2002), Ghazali and Weetman (2006), Al-Akra et al. (2010a). In addition, it supports that of Samaha and Dahawy $(2010 ; 2011)$ in the Egyptian context. This may be explained by the government's ability to access all company information. Agency theory suggests that, this reduces the monitoring costs, and hence reduces management incentives to improve disclosure. Simultaneously, Gray's (1988) accounting sub-cultural model, cost-benefit analysis, and institutional isomorphism all suggest that given the preference to secrecy the government may not encourage full transparency. This may be due to government's intention to sell its shares in the company at a good price as part of the privatisation programme. Additionally, the lack of awareness and the absence of incentives for members of the public who are implicit owners of government shares discourage direct monitoring of the management (generally government officials) of government-owned enterprises. This contributes to the decoupling problem as companies declare their compliance with IFRSs, simply to gain respect and legitimacy, when in reality they are not complying.

With respect to the association between management ownership ratio and levels of compliance with the overall IFRSs disclosure requirements, the findings reported in Table 3 do not support H5b (there is a significant negative statistical relationship between the management ownership ratio and the extent of compliance with IFRSs disclosure requirements). Although, this result does not agree with the findings of the majority of prior studies investigating the association between management ownership and levels of disclosure, which support a negative relationship (e.g., Eng \& Mak, 2003; Arcay \& Vazquez, 2005; Ghazali \& Weetman, 2006; Abdelsalam \& El-Masry, 2008), and with that of Samaha and Dahawy (2010) in the Egyptian context, it supports that of Samaha and Dahawy (2011). This may be explained by reduced agency costs, and predictions based on Gray's (1988) accounting sub-cultural model, costbenefit analysis, and institutional isomorphism that the secretive culture, lack of management awareness concerning the importance of transparency and compliance, absence of monitoring by board members or stock exchange regulators, and the absence of pressure from minority shareholders, encourage management to keep disclosure levels at a minimum as long as non-compliance costs are less than compliance costs. This in turn contributes to the problem of decoupling. With respect to the association between private ownership and levels of compliance with IFRSs disclosure requirements, the findings reported in Table 3 support H5c (there is no significant statistical relationship between the private ownership ratio and the extent of compliance with IFRSs disclosure requirements). This result supports the findings of Suwaidan (1997), Depeors (2000), and Al-Akra et al. (2010a,b); however, it does not support that of Samaha and Dahawy $(2010 ; 2011)$ with respect to voluntary disclosure practices in Egypt. This is probably attributable to ease of access to all company information by private investors who are in most cases actively involved in company management either as executives or as directors. Furthermore, based on Gray's (1988) accounting subcultural model, cost-benefit analysis, and institutional isomorphism, it can be stated that the secretive culture, and lack of private investor awareness of the importance of transparency will not increase pressures by private investors on management to improve compliance with IFRSs. Furthermore, absence of monitoring from board members or stock exchange regulators, and the absence of pressure from minority shareholders will reduce noncompliance costs; hence will not improve compliance levels with mandatory IFRSs. Consequently, this contributes to the problem of decoupling.

Finally, with respect to the association between public ownership ratio and levels of compliance with overall IFRSs disclosure requirements, the findings reported in Table 3 support H5d (there is no significant statistical relationship between the public ownership ratio and the extent of compliance with IFRSs disclosure requirements). This result supports that of Al-Akra et al. (2010a). However, it does not support the results of the majority of prior studies which support the existence of a positive association between public ownership and disclosure level (e.g., Haniffa, 1999; Haniffa \& Cooke, 2002; Al-Htaybat, 2005; Arcay \& Vazquez, 2005). In addition, it does not support the finding of Ezat and El-Masry (2008) in the Egyptian context. This result may be attributed to the reduced agency costs due to the lack of demand for more disclosure by naïve public investors in the Egyptian context. Furthermore, Gray's (1988) accounting sub-cultural model, cost-benefit analysis, and institutional isomorphism propose that the secretive culture 
causes management to avoid the outflow of stock market price-sensitive information. In addition, secrecy is also associated with large power distance and the tendency to collectivism (Gray, 1988). Furthermore, the lack of listed companies' management and BOD awareness regarding the importance of compliance with IFRSs and of following corporate governance best practices to enhance transparency, the weak enforcement of laws and regulations, and the absence of materially independent board members with primary responsibility for protecting public shareholders interests, cause non-compliance costs to be less than compliance costs. The fact that public shareholders in developing stock exchanges do not exercise their rights, adds to this situation, thereby management is not stimulated to improve compliance with IFRSs, and the problem of decoupling escalates. In this respect, Abdelsalam and Weetman (2007) argue that many public shareholders in Egypt are small investors who cannot form pressure groups like those in developed markets.

Regarding the association between company size and compliance with the overall IFRSs disclosure requirements, the results reported in Table 3 do not support a significant association. This supports the findings of Ahmed and Nicholls (1994), Street and Gray (2002) and Aljifri (2008). In addition, this supports the findings of Samaha and Dahawy $(2010 ; 2011)$ in the Egyptian context. This may be attributed to the similarity in compliance behaviour with mandatory IFRSs disclosure requirements among all companies listed on the EGX. Table 3 reveals that no association exists between firm profitability and its level of compliance with IFRS disclosure requirements in the Egyptian context, thereby supporting the findings of some previous studies (e.g., Eng \& Mak, 2003; Barako et al., 2006). In addition, it supports those of Abd-Elsalam (1999), Ezat and El-Masry (2008) and Samaha and Dahawy $(2010 ; 2011)$ in the Egyptian context. This may be explained by the similarity in compliance behaviour among all companies listed on the EGX. With respect to the association between firm gearing and its level of compliance with IFRSs disclosure requirements, Table 3 reveals that no association exists, thereby supporting research outcomes of some prior research (e.g.,Tower et al., 1999; Haniffa \& Cooke, 2002; Aksu \& Kosedag, 2006). In addition, it supports those of AbdElsalam (1999), Ezat and El-Masry (2008) and Samaha and Dahawy $(2010 ; 2011)$ in the Egyptian context. This may be explained by the similarities in compliance attitude among all companies listed on the EGX. Finally, Table 3 indicates that no association exists between firm liquidity and its level of compliance with IFRS disclosure requirements in the Egyptian context, thereby supporting the findings of Alsaeed (2005), Barako et al. (2006) and AlAkra et al. (2010a). In addition, it supports that of Abd-Elsalam (1999) and Samaha and Dahawy (2011) in the Egyptian context. This may be due to the similarity among all companies listed on the EGX in their compliance attitude with mandatory IFRSs disclosure requirements.

\subsubsection{Univariate Analysis - Total Disclosure Index and the Categorical Independent Variables}

The Mann-Whitney U test was used to determine whether there are significant statistical differences between the two groups of companies that: separate the CEO and Chair positions and those that do not; carry out manufacturing activities and those that carry out non-manufacturing activities; audited by big 4 affiliates and those audited by non big 4 ones. Table 4 presents the results of the Mann-Whitney U test.

Table 4. Mann-Whitney U Test Results for Categorical Independent Variables-Egypt.

\begin{tabular}{lllll}
\hline Disclosure Index & Mann-Whitney U & Wilcoxon W & Z & Asymp. Sig. (2-tailed) \\
\hline Board Leadership & & & \\
\hline $\begin{array}{l}\text { Total Disclosure Index } \\
\text { (Total Score) }\end{array}$ & 650.000 & 1353.000 & -.562 & .574 \\
\hline Type of Business Activity & & & \\
\hline $\begin{array}{l}\text { Total Disclosure Index } \\
\text { (Total Score) }\end{array}$ & 634.500 & 985.500 & -.028 & .978 \\
\hline Type of Auditor & & & \\
\hline $\begin{array}{l}\text { Total Disclosure Index } \\
\text { (Total Score) }\end{array}$ & 570.000 & 846.000 & -.322 & .748 \\
\hline
\end{tabular}


With respect to the impact of board leadership, the Mann-Whitney U test results demonstrated in Table 4 show that, no statistically significant differences exist between the two groups of companies (i.e., in which the CEO and Chair positions are held by different persons, and those that do not) in the extent of compliance with the overall IFRSs disclosure requirements as the probability value calculated is greater than .05 $(\mathrm{P}=.574)$. Consequently, H3: there are no statistically significant differences in the levels of compliance with IFRSs disclosure requirements between companies that separate the positions of the CEO and Chair and those that do not, is accepted. This supports the findings of Arcay and Vazquez (2005), Cheng and Courtenay (2006), Ghazali and Weetman (2006). In addition, it supports those of Ezat and El-Masry (2008) that carried out in the Egyptian context. This can be mainly explained by the lack of material independence of the Chair in the Egyptian listed companies when the CEO and Chair positions are separated. This in turn lends support to the institutional isomorphism which suggests that, separating the CEO and Chair positions has no influence on board leadership independence, as long as there is no awareness regarding the importance of separating the positions of the CEO and Chair in improving the monitoring of management behaviour and hence the quality of financial reporting within the business firm. Consequently, no significant impact on levels of compliance with IFRSs, is expected when the two positions are separated, and decoupling is thus expected to continue due to the existence of cultural barriers to understanding the logic behind the separation of the two positions as recommended under the Anglo-American model of corporate governance. In addition, companies may fall in line with the separation recommendations purely to gain respect and legitimacy. Also, Gray's (1988) accounting sub-cultural model, the notions of agency theory and cost benefit-analysis would argue that given the secretive culture accompanied with lack of material independence of the Chair, weak monitoring and lack of strict enforcement of compliance, non-compliance costs will continue to be less than compliance costs. Consequently, the separation between the CEO Chair positions will not result in better compliance with IFRSs disclosure requirements.

With respect to the impact of the type of business activity (manufacturing/non-manufacturing) on the levels of compliance with the overall IFRSs disclosure requirements, the Mann-Whitney U test results demonstrated in Table 4 show that, no statistically significant differences exist between the two groups of companies in the extent of compliance with the overall mandatory disclosure requirements as the probability value calculated is greater than .05 $(\mathrm{P}=.978)$. This supports the findings of some prior research (e.g., Naser, 1998; Naser at al., 2002; Street \& Gray, 2002). In addition, it supports those of Ismail et al. (2010) and Samaha and Dahawy (2011) in the Egyptian context. This may be attributed to the fact that companies listed on the EGX are the largest companies in their sectors and the most important vehicles in the development of the Egyptian economy, hence there are no differences in their attitude with respect to compliance with mandatory IFRSs disclosure requirements.

Finally, with respect to the impact of the type of auditor (big 4/non big 4) on the levels of compliance with the overall IFRSs disclosure requirements, the Mann-Whitney U test results demonstrated in Table 4 show that, no statistically significant differences exist between the two groups of companies in the extent of compliance with the overall mandatory disclosure requirements as the probability value calculated is greater than $.05(\mathrm{P}=.748)$. This supports the findings of some prior research (e.g., Naser, 1998; Naser et al., 2002; Street \& Gray, 2002). In addition, this supports the findings of Samaha and Dahawy $(2010 ; 2011)$ in the Egyptian context. Given that none of the companies that are listed on the EGX achieved full compliance with the overall level of compliance with mandatory IFRSs disclosure requirements, this implies that there is no difference between the quality of work performed by big 4 affiliates compared to non big 4 ones. Hence, this raises doubts concerning the quality of audit work performed by big 4 affiliates that operate in Egypt. Some of these audit firms may not be strict as they may consider the companies to be operating in a developing market, and to require more time to adapt to the compliance culture in respect of IFRSs. Additionally, they may fear the prospect of losing the client should they issue qualified reports; and another possibility is that they may perceive their clients as the best of the worst and believe that issuing them with qualified reports will give an advantage to those companies with lower compliance levels but audited by non-big 4 audit firms. This supports the continuity of decoupling problem in the Egyptian context in two ways. Firstly, listed companies will continue claiming that their financial statements are prepared in accordance with IFRSs while full compliance is absent. Secondly, it seems that in most cases, listed companies engage with big 4 audit firms, paying expensive audit fees merely as window dressing to attract more investors or to avoid extensive monitoring by the disclosure monitoring staff of the CMA.

The above discussion of the findings from the univariate analysis promulgates that none of the corporate governance variables has a significant association with the overall level of compliance with mandatory IFRSs disclosure 
requirements. This implies that the impact of corporate governance mechanisms that are recommended by the OECD principles and the ECCG is absent in the Egyptian context. For further confirmation a regression analysis was carried out using normal scores to investigate the joint effect of independent variables as will be seen in the next section.

\subsection{Regression results}

The regression model employed in this study failed to explain compliance behaviour with mandatory IFRSs disclosure requirements in the Egyptian context. This implies that the compliance behaviour with mandatory IFRSs disclosure requirements by companies listed on the EGX does not follow any pattern in relation to neither corporate governance related variables nor other company attributes under study in this research. From the researcher's point of view, the non-existence of a significant association between levels of compliance with mandatory IFRSs requirements and any of the company attributes that are employed as control variables is a positive sign that generally all companies listed on the EGX have similar attitude with respect to compliance with mandatory requirements (i.e., compliance with the majority of the requirements is now part of their culture). However, the lack of significant association between compliance levels and any of the corporate governance related variables implies that, the influence of corporate governance best practice on the levels of compliance with mandatory IFRSs in the Egyptian context is absent. This may be attributed to its novelty and the lack of awareness of the advantages of material compliance with its requirements in Egypt, meaning that as yet it is not part of the cultural values in the Egyptian context.

\section{Conclusion}

The disclosure indices of the 2007 annual reports of 75 non-financial companies listed on the EGX were tested for any association with corporate governance structures. The results indicated that the average level of compliance with total IFRSs disclosure requirements was $80 \%$. However, the univariate and multivariate analyses revealed that the influence of corporate governance structure on improving the extent of compliance with mandatory IFRSs disclosure requirements is absent. Hence, the introduction of corporate governance code that is based on the OECD principles in Egypt in 2005 did not achieve its potential. This result is consistent with the notions of the institutional isomorphism theory, Gray's (1988) accounting sub-cultural model, and the financial economics theories. Such consistency adds to the theoretical contribution of this study which can be considered the first to provide a competent comprehensive theoretical foundation of financial disclosure practices in the Egyptian context as one of the transitional economies in the Middle East.

\section{References}

Abd-Elsalam, O. H. 1999. The Introduction and Application of International Accounting Standards to Accounting Disclosure Regulations of a Capital Market in Developing Country: the Case of Egypt. Ph.D. thesis, Herriot-Watt University, UK.

Abd-Elsalam, O. H., and Weetman, P. 2003. Introducing International Accounting Standards to an Emerging Capital Market: Relative Familiarity \& Language Effect in Egypt. Journal of International Accounting, 12, 63-84.

Abdelsalam, O., and El-Masry, A. 2008. The Impact of Board Independence and Ownership Structure on the Timeliness of Corporate Internet Reporting of Irish-listed Companies. Managerial Finance, 34(12), 907-918.

Abdelsalam, O.H., and Street, D.L. 2007. Corporate Governance and the Timeliness of Corporate Internet Reporting by UK Listed Companies. Journal of International Accounting, Auditing and Taxation, 16, 111-130.

Abdelsalam, O.H., and Weetman, P. 2007. Measuring Accounting Disclosure in a Period of Complex Changes: The Case of Egypt. Advances in International Accounting, 20, 75-104.

Abed, S., Al-Okdeh, S, and Nimer, K. 2011. The Inclusion of Forecasts in the Narrative Sections of Annual Reports and their Association with Firm Characteristics: The Case of Jordan. International Business Research, 4(4), 264-271.

Ahmed, K., and Nicholls, D. 1994. The Impact of Non-Financial Company Characteristics on Mandatory Disclosure Compliance in Developing Countries: The Case of Bangladesh. The International Journal of Accounting, 29, 62-77.

Akhtaruddin, M. 2005. Corporate Mandatory Disclosure Practices in Bangladesh. The International Journal of Accounting, 40, 399-422.

Aksu, M., and Kosedag, A. 2006. Transparency and Disclosure Scores and their Determinants in Istanbul Stock Exchange. Corporate Governance, 14(4), 277-296.

Al-Akra, M., Eddie, I., and Ali, M.J. 2010a. The Influence of the Introduction of Accounting Disclosure Regulation on Mandatory Disclosure Compliance: Evidence from Jordan. The British Accounting Review, 42(3), 170-186. 
Al-Akra, M., Eddie, I., and Ali, M.J. 2010b. The Association between Privatisation and Voluntary Disclosure: Evidence from Jordan. Accounting and Business Research, 40(1), 55-74.

Al-Jifri, K. 2008. Annual Report Disclosure in a Developing Country: The Case of the UAE. Advances in Accounting Incorporating Advances in International Accounting, 24, 93-100.

Alsaeed, K. (2005).The Association between Firm-Specific Characteristics and Disclosure: The Case of Saudi Arabia. Journal of American Academy of Business, 7 (1). September, 310-321.

Al-Shammari, B., Brown, P., and Tarca, A. 2008. An Investigation of Compliance with International Accounting Standards by Listed Companies in the Gulf Cooperation Council Member States. The International Journal of Accounting, 43, $425-447$.

Arcay, M.R.B., and Vazquez, M.F.M. 2005. Corporate Characteristics, Governance Rules and the Extent of Voluntary Disclosure in Spain. Advances in Accounting, 21, 299-331.

Barako, D.G., Hancock, P., and Izan, H.Y. 2006. Factors Influencing Voluntary Corporate Disclosure by Kenyan Companies. Corporate Governance, 14(2), 107-125.

Beasley, M.S. 1996. An Empirical Analysis of the Relation between the Board of Directors' Composition and Financial Statement Fraud. The Accounting Review, 71(4), 443-465.

Belkaoui, A., and Kahl, A. 1978. Corporate Financial Disclosure in Canada. Research monograph of the Canadian Certified General Accountants Association. Vancouver.

Brown, R.Jr. 2007. Corporate Governance, the Securities and Exchange Commission, and the Limits of Disclosure. Catholic University Law Review, 57, 45-92.

Cadbury Committee Report. 1992. Report of the Cadbury Committee on the Financial Aspects of Corporate Governance. Tech. rept. Cadbury Committee, Gee. London.

Cheng, E.C.M., and Courtenay, S.M. 2006. Board Composition, Regulatory Regime, and Voluntary Disclosure. The International Journal of Accounting, 41, 262-289.

CIPE (2003).'Corporate Governance in Morroco, Egypt, Lebanon and Jordan- Countries of the MENA Region'. Middle East and North Africa Corporate Governance Workshop. The Center for International Private Enterprise.

Dahawy, K. (2007). Developing Nations and Corporate Governance. The Story of Egypt. Working Paper. Available: http://www.gcgf.org/ifcext/cgf.nsf/Content/Research?OpenDocument\&ExpandSection=-6\%2C5\%2C-4: Accessed 25/2/2010.

Dahawy, K., and Conover, T. 2007. Accounting Disclosure in Companies Listed on the Egyptian Stock Exchange. Middle Eastern Finance and Economics, 1, 5-20.

Denis, Diane, and McConnell, John. 2003. International Corporate Governance. Working paper. European Corporate Governance Institute.

Depoers, F. 2000. A Cost-Benefit Study of Voluntary Disclosure: Some Empirical Evidence from French Listed Companies. The European Accounting Review, 9(2), 245-263.

Desoky, A. 2009. Company Characteristics as Determinants of Internet Financial Reporting in Emerging Markets: The Case of Egypt. Research in Accounting in Emerging Economies, 9, 31-71.

Eng, L.L., and Mak, Y.T. 2003. Corporate Governance and Voluntary Disclosure. Journal of Accounting and Public Policy, 22(4), 325-345.

Ezat, A., and El-Masry, A. 2008. The Impact of Corporate Governance on the Timeliness of Corporate Internet Reporting by Egyptian Listed Companies. Managerial Finance, 34(12), 848-867.

Felo, A.J. (2009).Voluntary Disclosure Transparency, Board Independence and Expertise, and CEO Duality. Working Paper. Available: http:// ssrn.com/abstract=1373942. Accessed: 15/2/2010.

GAFI. 2007. Egyptian Code of Corporate Governance. Tech. rept. General Authority for Investment and Free Zones. Available: http://www.ecgi.org/codes/documents/egyptiancodeofcorporategovernance_en.pdf. Accessed: 25/2/2010.

Ghazali, N.A.M., and Weetman, P. 2006. Perpetuating Traditional Influences: Voluntary Disclosure in Malaysia Following the Economic Crisis. Journal of International Accounting, Auditing and Taxation, 15, 226-248.

Glaum, M., and Street, D.L. 2003. Compliance with the Disclosure Requirements of Germany's New Market: IAS versus US GAAP. Journal of International Financial Management and Accounting, 14(1), 64-100.

Gray, S.J. 1988. Towards a Theory of Cultural Influence on the Development of Accounting Systems Internationally. Abacus, 24(1), 1-15.

Gul, F.A., and Leung, S. 2004. Board Leadership, Outside Directors Expertise and Voluntary Corporate Disclosures. Journal of Accounting and Public Policy, 23, 351-379.

Haniffa, R.M., and Cooke, T.E. 2002. Culture, Corporate Governance and Disclosure in Malaysian Corporations. Abacus, 38(3), 317-349.

Healy, P.M., and Palepu, G. 2001. Information Asymmetry Corporate Disclosure, and the Capital Markets: A Review of the Empirical Disclosure Literature. Journal of Accounting and Economics, 31, 405-440. 
Ismail, T.H., Shehata, N.F., and Dahawy, K. 2010. Firm Characteristics Determinants and Disclosure Level in Emerging Market of Egypt' in Ismail, T. (2010). Perspective in Accounting Practices: Corporate Disclosure, Performance, Governance and Risk Management.

Jensen, M.C. 1993. The Modern Industrial Revolution, Exit, and the Failure of Internal Control Systems. The Journal of Finance, 48, 831-880.

Lakhal, F. 2003. Earning Voluntary Disclosures and Corporate Governance: Evidence from France. Available: http://papers.ssrn.com/sol3/papers.cfm? abstract $\_i d=500283$.

Mallin, C.A. 2009. Corporate Governance. 3 edn. New York: Oxford University Press.

Muslu, V. 2005. Effect of Board Independence on Incentive Compensation and Compensation Disclosure: Evidence from Europe. Working Paper. Available: http://www.ssrn.com. Accessed:23/9/2009.

Naser, K. 1998. Comprehensiveness of Disclosure of Non-Financial Companies Listed on the Amman Financial Market. International Journal of Commerce and Management, 8(1), 88-119.

Naser, K., Al-Khatib, K., and Karbhari, Y. 2002. Empirical Evidence on the Depth of Corporate Information Disclosure in Developing Countries: The Case of Jordan. International Journal of Commerce \& Management, 12, 122-155.

Naser, K., Al-Hussaini, A., Al-Kwari, D., and Nuseibeh, R. 2006. Determinants of Extent of Corporate Social Disclosure in Developing Countries: The Case of Qatar. Advances in International Accounting, 19(1-23).

OECD. 2004. Organization for Economic Cooperation and Development. Paris: OECD Principles of Corporate Governance, $O E C D$ Publications.

Owusu-Ansah, S., and Yeoh, J. 2005. The Effect of Legislation on Corporate Disclosure Practices. Abacus, 41(1), 92-109.

Samaha, K. 2006. Compliance with International Accounting Standards: Some Empirical Evidence from the Cairo \& Alexandria Sock Exchange. Accounting, Management \& Insurance Review, Cairo University Press.

Samaha, K. 2010. Do Board Independence and Audit Committees Motivate Disclosure on Different Corporate Governance Information Categories in the Annual Reports in Developing Countries? International Research Journal of Finance and Economics, 206-225.

Samaha, K., and Dahawy, K. 2010. Factors Influencing Corporate Disclosure Transparency in the Active Share Trading Firms: An Explanatory Study. Research in Accounting in Emerging Economies, 10, 87-118.

Samaha, K., and Dahawy, K. 2011. An Empirical Analysis of Corporate Governance Structures and Voluntary Corporate Disclosure in Volatile Capital Markets: The Egyptian Experience. International Journal of Accounting, Auditing and Performance Evaluation, 7(1/2), 61-93.

Suwaidan, M.S. 1997. Voluntary Disclosure of Accounting Information: the Case of Jordan. Ph.D. thesis, University of Aberdeen, UK.

Tricker, Bob. 2009. Corporate Governance: Principles, Policies and Practices. New York: Oxford University Press.

UNCTAD. 2007. Review of the Implementation Status of Corporate Governance Disclosures: Case Study Egypt. Tech. rept. Available: http://www.unctad. org/en/docs/c2isarcrp7\_en.pdf. Accessed 25/2/2010.

Wallace, R.S.O., and Naser, K. 1995. Firm-Specific Determinants of the Comprehensiveness of Mandatory Disclosure in the Corporate Annual Reports of Firms Listed in the Stock Exchange of Hong Kong. Journal of Accounting and Public Policy, 14, 311-368.

Zarzeski, M.T. 1996. Spontaneous Harmonization Effects of Culture and Market Forces on Accounting Disclosure Practices. Accounting Horizons, 10(1), 18-37 